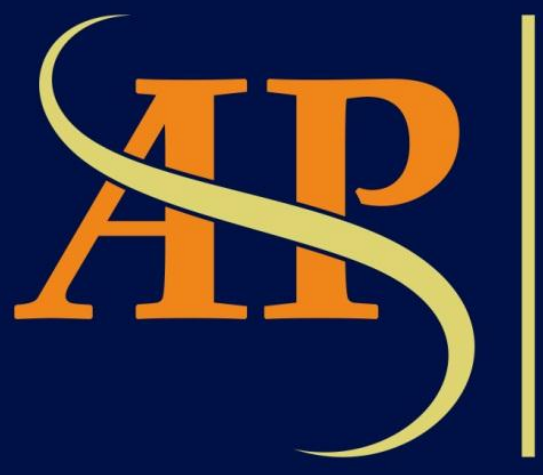

JURNAL

ASIA

PACIFIC

STUDIES

Journal of International Relations Study Program Faculty of Social and Political Sciences

Universitas Kristen Indonesia

Volume 2 | Number 2 | July - December 2018 


\title{
DIPLOMASI EKONOMI INDONESIA \\ DAN PASAR PROSPEKTIF DI KAWASAN PACIFIC ALLIANCE : STUDI KASUS MEKSIKO DAN CHILE
}

\author{
Leonard F. Hutabarat, Ph.D. \\ Hubungan Internasional, Fakultas Ilmu Sosial dan Ilmu Politik, Universitas Kristen Indonesia, \\ Jl. Mayjen Sutoyo No. 2, Jakarta 13630, Indonesia \\ Lfhutabarat@gmail.com
}

\begin{abstract}
This article argues that Indonesian economic diplomacy should consider Mexico and Chile as member of Pacific Alliance in Latin American region as the prospective markets for Indonesia in the future. As emerging economies, these two countries have positive economic projection, population growth and their demand for import products from other region. Based on economic diplomacy concept, Indonesian efforts to negotiate bilateral trade agreements (free trade agreement) or Comprehensive Economic Partnership Agreement (CEPA) with Mexico and Chile will be part of longterm strategy to build these countries as two of Indonesian non traditional markets.
\end{abstract}

Keywords : Economic Diplomacy, Pacific Alliance, Mexico, Chile

\begin{abstract}
Abstrak
Artikel ini berargumen bahwa diplomasi ekonomi Indonesia perlu mempertimbangkan Meksiko dan Chile yang merupakan negara anggota Aliansi Pasifik di kawasan Amerika Latin sebagai pasar prospektif bagi Indonesia pada masa yang akan datang. Sebagai emerging economies, kedua negara ini memiliki proyeksi ekonomi yang positif, pertumbuhan penduduk dan kebutuhannya terhadap produk-produk impor dari kawasan lain. Berdasarkan konsep diplomasi ekonomi, upaya-upaya Indonesia untuk menegosiasikan perjanjian-perjanjian perdagangan bilateralnya (perjanjian perdagangan bebas) atau Comprehensive Economic Partnership Agreement (CEPA) dengan Meksiko dan Chile akan menjadi bagian dari starategi jangka panjang untuk mengembangkan kedua negara ini sebagai dua pasar non tradisional Indonesia.
\end{abstract}

Kata Kunci : Diplomasi Ekonomi, Aliansi Pasifik, Meksiko, Chile 


\section{Pendahuluan}

Diplomasi ekonomi saat ini telah menjadi fokus kepentingan sebagian besar negara di dunia, termasuk Indonesia, sebagai upaya untuk mengembangkan perekonomian di masa mendatang. Sebagai salah satu dari 20 ekonomi terbesar dunia yang tergabung dalam Group of 20 (G-20), diplomasi ekonomi Indonesia difokuskan lebih lagi untuk mendorong ekspor, mempromosikan pariwisata dan meningkatkan perdagangan, pariwisata dan investasi (TTItrade, tourism, investment). Diplomasi ekonomi Indonesia juga diarahkan untuk memperkuat sistem kerja sama ekonomi bilateral dan regional, termasuk mengintensifkan kembali pembahasan Comprehensive Economic Partnership Agreement (CEPA) dengan beberapa negara maupun kawasan.

Di samping mempertahankan dan meningkatkan hubungan ekonomi dengan pasar tradisional, diplomasi ekonomi Indonesia terus memanfaatkan peluang pasar non-tradisional di semua kawasan, termasuk di kawasan Amerika. Untuk kawasan Amerika, peluang pasar non-tradisional berada di wilayah Amerika Latin yang memiliki beberapa emerging economies, dan berpotensi besar sebagai pasar non-tradisional yang belum dioptimalkan baik dari aspek perdagangan, pariwisata, dan investasi, termasuk di kawasan Pacific Alliance.

Kondisi tersebut memunculkan kebutuhan untuk memberikan respon kebijakan luar negeri yang disesuaikan dengan dinamika yang terus berkembang, salah satunya dengan memanfaatkan munculnya emerging economies di kawasan Pacific Alliance, khususnya Chile dan Meksiko guna memperoleh manfaat yang besar bagi pencapaian kepentingan nasional. Tulisan ini akan menjawab rangkaian pertanyaan yaitu perkembangan apa saja yang saat ini terjadi di kawasan Amerika yang perlu mendapatkan perhatian dan apa dampaknya dalam merumuskan diplomasi ekonomi ke kawasan tersebut, negara-negara mana saja di kawasan Pacific Alliance yang merupakan pasar non-tradisional yang prospektif bagi Indonesia, dan strategi apa saja, khususnya di bidang ekonomi (perdagangan, pariwisata dan investasi), yang harus dipersiapkan Indonesia dalam upaya menembus pasar-pasar non-tradisional di kawasan Pacific Alliance.

\section{Tantangan Ekonomi Global Munculnya Kekuatan Ekonomi Baru (Emerging Market Economies/EME)}

Dalam World Economic Outlook 2018, International Monetary Fund (IMF) memprediksikan bahwa perekonomian dunia mulai membaik dan beberapa negara emerging economies menunjukkan trend yang positif. Pertumbuhan global 2017 diprediksi mencapai 3,7\% dan diharapkan dapat menjadi 3,9\% pada tahun 2018 dan 2019. Sementara di kawasan Amerika Latin, pemulihan ekonomi bertumbuh pada 1,9\% pada tahun 2018 dan diharapkan dapat mencapai 2,6\% pada tahun 2019. Perkembangan ini dipengaruhi meningkatnya kondisi di Meksiko dengan pemulihan ekonomi Brazil.

Selain itu juga terdapat tantangan-tangan seerti inward-looking policies dan faktorfaktor ketegangan geopolitik seprti di Timur Tengah dan Asia Timur. Hal lain yang juga mempengaruhi perkembangan extreme weather di Atlantik, kekeringan di kawasan sub Saharta Arika dan Australia, yang akan menimbulkan dampak kemanusiaan bagi kawasan tersebut. Tantangan-tantangan tersebut tentunya akan mempengaruhi kebijakan ekonomi luar negeri Indonesia yang patut disesuaikan dengan dinamika sistem ekonomi global saat ini.

Hal tersebut telah membawa tantangan baru bagi negara-negara demokrasi berkembang, termasuk di Indonesia, untuk bersaing dengan negara-negara dengan sistem perekonomian yang lebih maju seperti negara-negara di kawasan Eropa Barat dan Amerika 
Serikat. Pertumbuhan ekonomi yang tinggi juga dibutuhkan mengingat kondisi kesejahteraan sosial masyarakat di Indonesia terbilang cukup rendah dan kesenjangan ekonomi yang tak kunjung mendapatkan perbaikan. Melalui diplomasi ekonomi yang aktif, diharapkan Indonesia dapat mencapai stabilitas dan kemajuan sistem ekonomi.

Terdapat berbagai definisi mengenai EME. Kriteria IMF dalam membagi perekonomian dunia advanced economies, emerging market dan developing economies didasarkan pad: (1) pendapatan per kapita; (2) diversifikasi ekspor; dan (3) tingkat integrasi pada sistem keuangan global. Namun kriteria ini sangat fleksibel dan dapat berubah sesuai perkembangan (IMF 2016). Di kawasan Amerika dan Eropa Advanced economies didefinisikan sebagai negara-negara pasca industri dengan pendapatan per kapita yang tinggi, industri yang kompetitif dan infrastruktur yang maju seperti AS, negara-negara Eropa Barat, dan Kanada. EME adalah negara yang berkembang yang telah mencapai industrialisasi, modernisasi dan pertumbuhan yang cukup signifikan seperti Armenia, Belarussia, Albania, Bulgaria, Kroasia, Republic Ceko, Estonia, Hungaria, Latvia, Lithuania, Polandia, Romania, Republic Slovakia, dan Slovenia. Sedangkan developing economies adalah negara-negara berpendapatan dan industri yang terbatas serta ekonomi yang stagnan seperti Bangladesh dan Bolivia (Cavusgil, S. Tamer, Gary Knight, \& John R. Riesenberger 2013).

Tabel 1. Emerging Market Economies

\begin{tabular}{|c|c|}
\hline Commonwealth of independent states (8) & $\begin{array}{l}\text { Armenian, Belarussia, Kazakhstan, } \\
\text { Republic, Moldova, Russia, Ukraine }\end{array}$ \\
\hline Cooperation council for the Arab States of gulf (1) & Saudi Arabia \\
\hline East Asia (10) & $\begin{array}{l}\text { China, India, Indonesia, Korea, Malaysia, } \\
\text { Phillipines, Srilanka, Taiwan Province of China, } \\
\text { Thailand, Vietnam }\end{array}$ \\
\hline Eastern Europe (12) & $\begin{array}{l}\text { Albania, Bulgaria, Croatia, Czech Republic, } \\
\text { Estonia, Hungary, Latvia, Lithuania, Poland, } \\
\text { Romania, Slovak Republic, Slovenia }\end{array}$ \\
\hline Latin America (12) & $\begin{array}{l}\text { Argentina, Brazil, Chile, Colombia, Costa Rica, } \\
\text { Ecuador, El Salvador, Guatemala, Mexico, } \\
\text { Paraguay, Peru, Uruguay }\end{array}$ \\
\hline Other Emerging Markets (2) & South Africa, Turkey \\
\hline
\end{tabular}

Sumber: IMF, 2016

IMF membagi 45 negara di dunia sebagai negara dengan ekonomi yang berkembang (EME). Di kawasan Eropa, EME adalah negara-negara Eropa Tengah dan Timur seperti adalah Albania, Bulgaria, Kroasia, Estonia, Hungaria, Polandia, Slovenia, Slovakia, Ceko, Romania dan Turki. Di Benua Amerika, EME adalah negara di Amerika Latin seperti Meksiko, Chile, Argentina, Brazil, Costa Rica, El Salvador, Kolombia Guatemala, Paraguay, Peru dan Uruguay. EME menikmati standar kehidupan yang semakin tinggi dan pertumbuhan ekonomi yang melebihi negara maju.

Fenomena bergesernya perekonomian dari advanced economies ke EME antara lain disebabkan oleh tingkat pertumbuhan ekonomi yang tinggi, dan terbukanya pasar bebas, lebih terintegrasi pada sistem perekonomian dunia, ketersediaan sumber daya alam (pertambangan, pertanian, perkebunan), serta sumber daya manusia yang jumlahnya mencukupi serta kompetitif dari segi skill dan standar penggajian. Hal ini merupakan faktor yang menyebabkan negara-negara EME sebagai negara-negara yang menarik bagi investasi asing, negara dengan target pasar yang besar, dan destinasi sumber daya. Kebangkitan EME merupakan faktor yang mempengaruhi perekonomian global pada abad ini. Walaupun perekonomian negara maju 
telah menunjukkan pemulihan krisis, dan emerging markets memasuki periode perlambatan, namun pertumbuhan ekonomi global akan selalu dipengaruhi oleh emerging markets (Icef Monitor 2014).

\section{Diplomasi Ekonomi Indonesia}

Konsep diplomasi ekonomi awalnya diperkenalkan oleh Jepang setelah kekalahannya pada Perang Dunia II dalam upaya untuk meningkatkan aktivitas pasar dan memenuhi permintaan akan sumber daya. Pada tahun 1950-an, Pemerintah Jepang merumuskan konsep diplomasi ekonomi dan secara aktif diimplementasikan dalam hubungannya dengan negaranegara di Asia Tenggara. Secara bertahap, Jepang mulai membuka pasar Asia Tenggara dan memberikan bantuan ekonomi dan membantu beberapa negara di kawasan tersebut untuk meningkatkan infrastruktur dan memperbaiki iklim investasi. Pada dasarnya, diplomasi ekonomi merupakan aktivitas resmi diplomatik yang difokuskan pada tujuan kepentingan ekonomi suatu negara dalam level internasional, yang mencakup upaya peningkatan ekspor, menarik investasi asing, dan partisipasi kerja dalam berbagai organisasi ekonomi internasional. Sama halnya dengan diplomasi tradisional, diplomasi ekonomi berupaya untuk mempengaruhi kebijakan ekonomi eksternal guna mencapai kepentingan nasional. Menurut Kishan S. Rana, "diplomasi ekonomi merupakan suatu proses dimana negara berhubungan dengan dunia luar dalam upaya memaksimalkan tujuannya di segala bentuk aktivitas, seperti perdagangan, investasi, dan bentuk lainnya dari interaksi ekonomi” (Rana 2007).

Faktor-faktor yang mempengaruhi perkembangan peran dan fungsi diplomasi ekonomi antara lain adalah: 1) proses internasionalisasi dan penguatan dependensi sistem ekonomi dunia; 2) ekspansi pada ekonomi pasar, liberalisasi perekonomian nasional, dan peningkatan interaksi negara melalui perdagangan dan investasi internasional, serta peningkatan aktor ekonomi global; 3) globalisasi ekonomi (gabungan antara proses internasionalisasi dan peningkatan peran perusahaan multinasional) yang berdampak pada peningkatan peran diplomasi ekonomi. Dalam hal ini, diplomasi ekonomi berperan dalam mendorong perkembangan internasionalisasi di negara, namun disisi lain juga menahan kekuatan dari negara atau aktor lain yang berusaha memonopoli keuntungan dari globalisasi tersebut; 4) adaptasi terhadap metode manajemen progresif, efisiensi energi, dan teknologi baru; dan 5) perkembangan inovasi ekonomi negara terhadap keterbukaan ekonomi eksternal (Baranay 2009).

Diplomasi ekonomi tidak lepas dari faktor politik suatu negara dan saling berkaitan antara kesejahteraan (prosperity) atau 'business end' dan kestabilan politik atau 'power-play end'. Penggerak kegiatan-kegiatan diplomasi ekonomi adalah tujuan strategis dari suatu pemerintah dan perhitungan-perhitungan matang terkait cost dan benefit yang berdasar pada logika politik. Oleh karena itu, diplomasi ekonomi dapat didefinisikan sebagai pemanfaatan alat politik internasional untuk mencapai tujuan-tujuan ekonomi melalui berbagai kerja sama seperti pembangunan (termasuk kesehatan, pendidikan dan pertanian), energi, lingkungan hidup, keuangan, dan pangan.

Pelaku utama diplomasi ekonomi adalah negara. Namun demikian, non-state actors juga merupakan pelaku diplomasi ekonomi, sehingga sangat memungkinkan kegiatan diplomasi ekonomi dilakukan oleh pelaku usaha antara dua negara (B-to-B). Munculnya berbagai aktor, di samping pelaku-pelaku tradisional dalam diplomasi ekonomi, sudah bukan merupakan hal baru dalam hubungan ekonomi internasional. Di samping kementerian teknis, aktor lain seperti komunitas bisnis, lembaga swadaya masyarakat dan lembaga-lembaga lain semakin berperan dalam diplomasi ekonomi, terutama dengan semakin canggihnya teknologi 
informasi dan komunikasi. Kesuksesan diplomasi ekonomi ditandai dengan selarasnya simpul-simpul ekonomi eksternal dan internal yakni integrasi promosi perdagangan dan investasi, serta kebijakan domestik perdagangan dan bantuan luar negeri. Kebijakan ini telah banyak diambil oleh negara-negara Skandinavia (Denmark, Finlandia, Norwegia, Swedia, Islandia) dan negara lain seperti Australia, Brunei, Kanada, Korea Selatan, Selandia Baru serta beberapa negara di Karibia.

Dalam The Changing Politics of Foreign Policy, Christopher Hill menegaskan bahwa diplomasi ekonomi berawal dari kebutuhan untuk mempromosikan kesejahteraan nasional dan menjalankan kebijakan ekonomi luar negeri. Diplomasi ekonomi umumnya bersifat lebih rutin dari bantuan Marshall Plan atau bantuan IMF. Diplomasi ini biasanya terdiri dari bantuan untuk mendorong ekspor perusahaan-perusahaan negara dan menarik investasi ke dalam yang dapat menciptakan lapangan pekerjaan. Bagi sektor swasta, usaha mendapatkan kontrak dengan negara lain seringkali membutuhkan bantuan negosiasi G-to-G. Disinilah diplomasi ekonomi berjalan, yakni dimana bisnis tidak dapat berjalan tanpa melibatkan diri dengan politik dan diplomasi (Hill 2003).

Berdasarkan uraian di atas, maka "diplomasi ekonomi dapat dipahami sebagai penggunaan sarana politik sebagai leverage dalam negosiasi internasional, dengan tujuan untuk meningkatkan kesejahteraan ekonomi nasional, dan penggunaan leverage ekonomi untuk meningkatkan stabilitas politik suatu negara" (Okano-Heijmans 2013). Dalam upaya mencapai kesejahteraan dan kestabilan politik, dapat dilakukan melalui berbagai jenis diplomasi ekonomi, yaitu dengan commercial diplomacy, trade diplomacy, financial diplomacy maupun sanctions. Konsep mengenai diplomasi ekonomi ini dijelaskan secara komprehensif oleh Okano-Heijmans, termasuk berbagai upaya negosiasi FTA secara bilateral maupun regional yang dilakukan banyak negara dalam grafik di bawah ini:

Gambar 1. Konsep Diplomasi Ekonomi

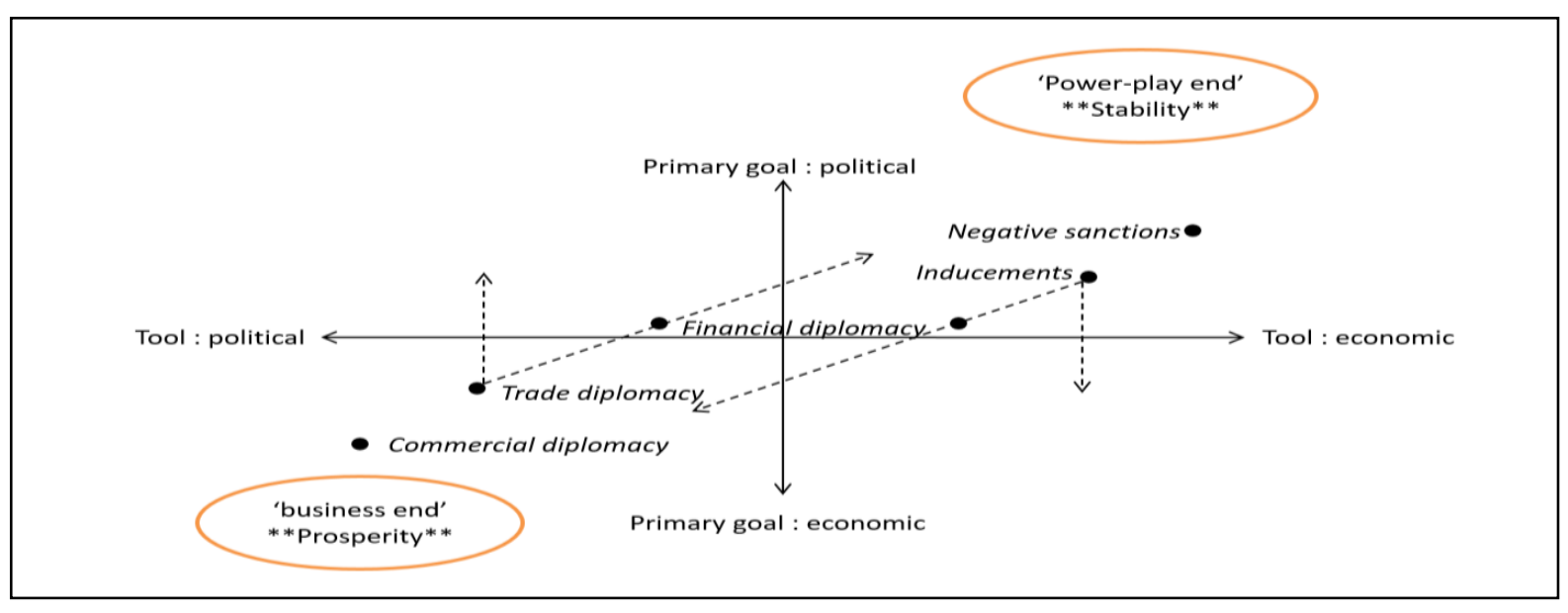

Sumber: Maaike Okano-Heijmans. Economic Diplomacy: Japan and the Balance of National Interest

Diplomasi ekonomi juga mencakup berbagai dimensi. Pertama, dimensi bilateral, yang berupa kegiatan ekonomi antara dua negara, seperti perjanjian perdagangan atau free trade agreement (FTA) antara dua negara. Kedua, dimensi regional, yang berupa perjanjian ekonomi yang disepakati oleh negara-negara dalam suatu kawasan, seperti Regional Economic Comprehensive Partnership (RCEP) atau Asia Pacific Economic Cooperation (APEC). RCEP diperkenalkan tanggal KTT ASEAN ke-19 di Bali, tanggal bulan November 
2011. RCEP terdiri atas 10 negara anggota ASEAN dan Australia, RRT, Jepang, India, Korea Selatan dan Selandia Baru. Total perekonomian RCEP mencapai USD 22,7 triliun atau sebesar 29,3\% dari perekonomian dunia. Tanggal tahun 2014 total perdagangan RCEP mencapai USD 10,8 triliun atau sekitar 28, 4\% perdagangan dunia. FDI yang masuk ke negara RCEP mencapai USD 366,3 miliar atau 29,8\% dari total FDI dunia. Ketiga, dimensi multilateral, seperti negosiasi perdagangan yang terjadi di World Trade Organization (WTO). Putaran Perundingan WTO terakhir dilaksanakan tanggal tahun 2001 di Doha menghasilkan Doha Development Agenda yang bertujuan untuk meningkatkan prospek perdagangan berkembang. Selain itu telah dilaksanakan Konferensi Tingkat Menteri (KTM) ke-9 di Bali tanggal tanggal 3-7 Desember 2013 dan KTM ke-10 di Nairobi tanggal tanggal 15-19 Desember 2015.

Dalam konteks tersebut di atas dan sesuai dengan grafik diplomasi ekonomi OkanoHeijmans, tujuan akhir diplomasi ekonomi Indonesia dapat dilihat untuk mencapai kesejahteraan masyarakat, atau 'business-end' prosperity. Hal ini juga sesuai dengan tujuan diplomasi Indonesia yang membumi (down-to-earth) dan terkoneksi dengan kepentingan rakyat (people-centered) dengan tujuan untuk mendukung kemandirian di bidang pangan dan energi, terutama energi baru dan terbarukan, serta guna menopang kemandirian ekonomi nasional.

Terus mengecilnya sektor industri berdampak pada mengecilnya share Indonesia pada pasar-pasar tradisional tujuan ekspor Indonesia. Data dari International Trade Centre menunjukan bahwa perkembangan ekspor Indonesia dalam kurun waktu 2011-2015 di beberapa negara besar di Amerika seperti Amerika Serikat, Kanada, Chile, Brasil, Kolombia, Panama, dan Argentina tidak lebih besar dari ekspor negara kompetitor-kompetitor Indonesia ke tujuan negara dimaksud di atas, sehingga kemungkinan pasar untuk produk ekspor yang sama terjadi kompetisi yang justru melemahkan Indonesia. Namun di sisi lain ekspor produk Indonesia ke pasar non-tradisional seperti Meksiko dan Peru di periode yang sama terus meningkat sehingga persentasinya menjadi lebih besar dari ekspor dari negara lain.

Kondisi geoekonomi global saat ini dan di masa mendatang juga akan menghadirkan tantangan bagi perekonomian Indonesia. Tantangan tersebut antara lain adalah: Pertama, semakin meningkatnya hambatan non tarif di negara tujuan ekspor. Hal ini merupakan salah satu akibat dari krisis global yang terjadi beberapa tahun lalu, dimana masing- masing negara cenderung untuk mengamankan pasar domestiknya melalui upaya penerapan hambatan perdagangan yang berupa non tariff measures (NTMs) dan non tariff barriers (NTBs). Pada periode 2015, jumlah NTMs di dunia meningkat dengan sangat pesat, seperti: seperti: Sanitary-and-Phytosanitary dan export taxes/restriction. Sementara itu, apabila dilihat dari sebaran geografisnya, NTMs banyak diterapkan oleh Uni Eropa, India, Rusia dan Amerika Latin.

Kedua, pergeseran fenomena kerjasama ekonomi ke arah plurilateral dan mega blok. Hal ini berangkat dari kesadaran bahwa kerjasama plurilateral dapat mengurangi kerumitan yang terjadi (noodle bowl syndrome) akibat banyaknya kesepakatan bilateral. Pergeseran paradigma arsitektur kerjasama ekonomi global tidak berhenti sampai di tingkat plurilateral, karena saat ini telah berkembang keinginan negara-negara untuk membangun konstelasi kerjasama ekonomi yang lebih luas. Tiga kesepakatan kerjasama ekonomi yang sedang dalam proses perundingan, ke depan diperkirakan akan menjadi tiga Mega Blok Perdagangan (Mega Trading Block), yaitu: TPP (Trans Pacific Partnership) yang saat ini beranggotakan 13 negara Asia dan Pasifik, TTIP (Trans Atlantic Trade and Investment Partnership) yang terdiri dari Amerika dan EU, serta RCEP (Regional Comprehensive Economic Partnership) yang terdiri dari 10 negara ASEAN dan 6 negara mitra ASEAN. Ketiga mega blok perdagangan ini diperkirakan akan menjadi penentu arsitektur perdagangan dan investasi global 


\section{Pasar Prospektif di Kawasan Amerika Latin}

Dengan gambaran umum potensi ekonomi kawasan Amerika Latin dapat diidentifikasi dua negara yang dapat dijadikan fokus penguatan diplomasi ekonomi Indonesia di pasar prospektif. Penetapan negara target tersebut akan merujuk pada Market Potential Index (MPI) - yang memetakan potensi pasar dari 87 emerging economies berdasarkan delapan indikator ekonomi dan politik. Kajian ini menggunakan Market Potential Index (MPI) yang disusun sejak tahun 1996 oleh lembaga International Business Center, Michigan State University, Amerika Serikat berdasarkan 8 indikator yaitu: (a) market size; (b) market growth; (c) market intensity; (d) market consumption capacity; (e) commercial infrastructure; (f) economic freedom; (g) market receptivity; dan (h) country risk (GlobalEdge 2016) dan mempertimbangkan faktor-faktor kualitatif, seperti aspek geostrategis, geopolitik, dan hubungan bilateral negara-negara target tersebut dengan Indonesia.

Kawasan Amerika dan Eropa menjadi rumah bagi sejumlah mitra dagang dan ekonomi utama (mitra tradisional) Indonesia. Amerika Serikat (AS), Kanada, Uni Eropa (UE), dan Rusia selama ini telah menjadi beberapa destinasi utama bagi pasar produk ekspor Indonesia, sumber investasi dan wisatawan mancanegara (wisman), serta mitra pembangunan dan alih teknologi. Namun demikian, dinamika ekonomi global, seperti lambatnya pemulihan ekonomi global, menurunnya perdagangan dunia, dan melemahnya perekonomian RRT, telah mendesak berbagai negara di dunia, termasuk Indonesia, untuk memperluas pasar alternatif dan memperkuat diplomasi ekonominya dengan berbagai mitra ekonomi baru atau nontradisional.

Dalam konteks kawasan Amerika dan Eropa, terdapat beberapa dinamika yang mendorong perlunya penguatan diplomasi ekonomi Indonesia guna mengoptimalkan peluang di pasar-pasar prospektif secara lebih optimal, yaitu: (a) tren penurunan permintaan pasar Amerika dan Eropa; (b) risiko geopolitik akibat gejolak sosial-politik di Amerika dan Eropa; dan (c) menguatnya persaingan negara-negara dalam memperebutkan pasar prospektif di kawasan Amerika dan Eropa, khususnya Amerika Latin (Pramono 2016).

\subsection{Penurunan Permintaan Pasar Utama di Kawasan Amerika dan Eropa}

Selama 5 tahun terakhir, AS dan UE termasuk dalam 5 besar mitra dagang Indonesia. Pada tahun 2015, berdasarkan data International Trade Center, perdagangan Indonesia-AS mencapai USD 23,8 miliar. Nilai ekspor Indonesia ke AS tercatat USD 16,2 miliar $(10,8 \%$ dari total ekspor Indonesia) dan impor dari AS sebesar USD 7,6 miliar (5,3\% dari total impor Indonesia). Sedangkan perdagangan antara Indonesia-UE pada tahun 2015 mencapai USD 26,1 miliar. Indonesia mencatatkan total ekspor ke UE sebesar USD 14,8 miliar (9,9\% dari ekspor Indonesia) dan impor dari UE sebesar USD 11,3 miliar (7,9\% dari impor Indonesia). Namun demikian, pemulihan ekonomi yang berlangsung moderat (mild recovery) sejak krisis keuangan global 2008-2009 telah berdampak, antara lain, pada penurunan permintaan impor dari pasar-pasar utama Indonesia di Amerika dan Eropa.

Proyeksi IMF yang dirilis pada Oktober 2016 menyatakan bahwa perekonomian AS akan tumbuh 1,6\% (2016) dan 1,7\% (2017); Kanada tumbuh 1,2\% (2016) dan 1,9\% (2017); zona Euro tumbuh 1,7\% (2016) dan 1,5\% (2017); sedangkan Rusia masih akan berkontraksi 0,8\% (2016) dan tumbuh 1,1\% (2017) (IMF 2016). Tren yang diperkirakan masih akan berlangsung sampai beberapa tahun ke depan ini dikhawatirkan belum mampu meningkatkan permintaan dunia. Hal ini pada gilirannya akan menyulitkan kinerja ekspor Indonesia karena permintaan impor dari mitra dagang utama akan cenderung melemah sebagaimana tercermin 
selama kurun 2011-2015. Nilai impor AS dari dunia bergerak naik hanya 1\% sedangkan Kanada tumbuh negatif 1\%. Di kawasan Eropa, pertumbuhan impor Jerman, Belanda, Perancis, dan Inggris dari dunia tumbuh negatif sekitar 3\%.

Dalam konteks bilateral dengan Indonesia, untuk periode 2011-2015, nilai impor mitra dagang tradisional Indonesia umumnya juga menunjukkan pertumbuhan negatif. Ekspor Indonesia ke pasar AS dan Rusia tumbuh moderat masing-masing 1\% dan 5\%, sementara ke sebagian besar pasar negara-negara UE, ekspor Indonesia mengalami pertumbuhan negatif. Tren ini lebih jelas terlihat pada periode 2014-2015 dimana kinerja ekspor Indonesia ke mitra dagang utama di Amerika dan Eropa umumnya tumbuh negatif.

Krisis keuangan global 2008 telah membuktikan bahwa diversifikasi pasar menjadi suatu hal yang harus dilakukan. Ketergantungan yang tinggi terhadap pasar tertentu sangat berisiko bagi perekonomian suatu negara, apalagi dalam situasi krisis ekonomi. Risiko ini dapat terlihat pada kinerja ekspor Indonesia tahun 2009. Sebagai dampak dari krisis ekonomi global tahun 2008, ekspor Indonesia ke pasar utama - AS, RRT, Jepang, Malaysia, dan Singapura - yang berkontribusi $47 \%$ terhadap total ekspor Indonesia pada tahun 2009 menurun 2,7\% dari nilai ekspor tahun 2004 (Kemendag 2016).

Menurut data International Trade Center (ITC), pada tahun 2015, ekspor UE-28 ke AS mencakup 18,2\% dari total ekspornya sementara ekspor Eropa secara keseluruhan ke AS mencapai 20,6\% dari total ekspor Eropa. Sedangkan impor AS dari UE-28 dan Eropa mencakup masing-masing $18,9 \%$ dan $21,3 \%$ total impor AS. Sedangkan dari sisi investasi, pada tahun 2013, investasi langsung UE-28 mencapai €276 miliar (sekitar USD 288,2 miliar), sedangkan investasi langsung AS ke UE-28 mencapai €433,4 miliar (sekitar USD 452,1 miliar). AS juga merupakan mitra utama UE dalam hal investasi portofolio (Eurostat 2016) Selain itu, mitra ekonomi utama Indonesia di ETT yakni Rusia juga tengah mengalami penurunan ekonomi akibat turunnya harga minyak dunia sehingga daya serap Rusia terhadap produk ekspor melemah, khususnya produk Crude Palm Oil/CPO asal Indonesia, dan mulai beralih ke Asia.

Kondisi di atas menjadi faktor pendorong bagi Indonesia untuk mengembangkan pasar alternatif di kawasan Amerika Latin dan ETT. Meningkatnya proporsi konsumsi domestik terhadap GDP dan meningkatnya tren impor dan daya beli masyarakat di kedua kawasan tersebut menjadikan kawasan Amerika Latin sangat potensial sebagai pasar alternatif.

\subsection{Menguatnya Persaingan dalam Memperebutkan Pasar Alternatif}

Persaingan antarnegara dalam merebut pasar alternatif semakin ketat. Ketidakpastian ekonomi di Amerika dan Eropa selama beberapa tahun terakhir menjadikan tidak hanya Indonesia, namun juga negara lainnya di dunia, mencari solusi untuk mengantisipasi kondisi perekonomian dalam negerinya yang secara langsung maupun tidak langsung terpengaruhi, salah satunya dengan memprioritaskan pengelolaan pasar prospektif di kawasan Amerika Latin. Dalam memperluas akses pasar dan memperdalam hubungan ekonominya dengan Amerika Latin, Indonesia akan bersaing dengan negara-negara adikuasa maupun negaranegara berkembang berdaya saing tinggi dan memiliki kekuatan modal, seperti AS dan RRT, UE, Vietnam dan Malaysia, yang semakin gencar menjalin kemitraan ekonomi dengan kawasan ini.

Berbagai fenomena di atas menuntut adanya upaya diplomasi ekonomi yang senantiasa beradaptasi dengan perkembangan dinamika global dan regional. Menurut Mark Webber dan Michael Smith, dalam bukunya Foreign Policy in a Transformed World, politik luar negeri suatu negara dapat dikatakan baik apabila dapat merespon perubahan situasi global 
dengan baik dan bergerak dari paradigma lama bahwa politik luar negeri semata-mata ditujukan untuk mencapai kepentingan nasional dalam definisi yang sempit: memelihara keamanan negara, memperjuangkan kedaulatan negara.

Paradigma baru pasca Perang Dingin tersebut oleh Robert Keohane dan Joseph Nye (1989) disebut sebagai "saling ketergantungan yang kompleks" atau complex interdependence yang merujuk pada hubungan resiprokal atau timbal balik antaraktor global - negara maupun non-negara - yang ditandai dengan tiga macam unsur, yaitu multiple channels, multiple issues, dan less strategic-military aspect (Rana 2015).

(a) saluran yang beragam berarti melibatkan banyak aktor, pejabat negara, perusahaan transnasional, NGOs, civil society groups (pekerja, petani, nelayan, UMKM, kaum profesional) dalam multi-track diplomacy atau total diplomacy.

(b) isu yang beragam mencakup politik-keamanan (kerja sama militer, pakta pertahanan, kerja sama antar-lembaga), ekonomi (perdagangan, investasi, teknologi), sosial, dan budaya (olahraga, kesenian, pariwisata).

(c) berkurangnya dimensi militer-strategis (less strategic-military dimension) berarti berkurangnya relevansi penggunaan kekuatan militer dalam mengatasi berbagai ancaman baru (traficcking, terorisme, kerusakan lingkungan).

Dalam konteks tersebut, Max Webber dan Michael Smith mengharapkan bahwa polugri dapat responsif melalui tiga macam transformasi: (a) transformasi pada dimensi "lokus kegiatan" yang tidak lagi berpusat di satu kawasan saja sebaik prioritas, tetapi membuka diri bagi seluruh kawasan seperti Amerika Selatan, Asia dan Afrika; (b) transformasi pada dimensi fokus kegiatan yang tidak lagi didominasi oleh isu-isu khas Perang Dingin seperti kegiatan untuk menjamin keamanan negara; dan (c) transformasi pada dimensi intrumen yang digunakan dalam aktivitas hubungan inernasional termasuk menggunakan soft power berupa nilai, norma, dan budaya.

Berdasarkan pemikiran di atas, diplomasi ekonomi Indonesia perlu beradaptasi untuk mengantisipasi hal tersebut, dengan mencari mitra baru di luar lingkaran hubungan Indonesia dengan mitra tradisionalnya atau mitra strategis sebagaimana tergambar pada tabel berikut ini. Penguatan hubungan ekonomi perlu dilakukan pada lapisan lain, khususnya lapisan kedua (kategori penting), atau pada kategori strategis ketika hubungan bilateral mengalami penurunan karena berbagai faktor.

\section{Diplomasi Ekonomi ke Kawasan Amerika Latin sebagai Pasar Prospektif Bagi Indonesia}

Amerika Latin merupakan kawasan yang memiliki potensi besar dalam rangka ekspansi pasar non-tradisional. Amerika Latin yang terdiri dari 33 negara (Goodwin 2011) memiliki luas benua terluas ke-2 dengan $42.292 .000 \mathrm{~km}$ persegi dan jumlah populasi 954 juta (2013), dimana 65\% populasi bertempat di tiga negara: Amerika Serikat, Meksiko, dan Brasil. Total GDP kawasan ini mencapai lebih dari USD 5,5 triliun, diantaranya ada tiga perekonomian yang berada dalam kelompok 20 negara maju (G-20), yaitu Brasil, Meksiko dan Argentina. 


\section{Gambar 2. Peta Posisi Geografis Indonesia-Amerika Latin}

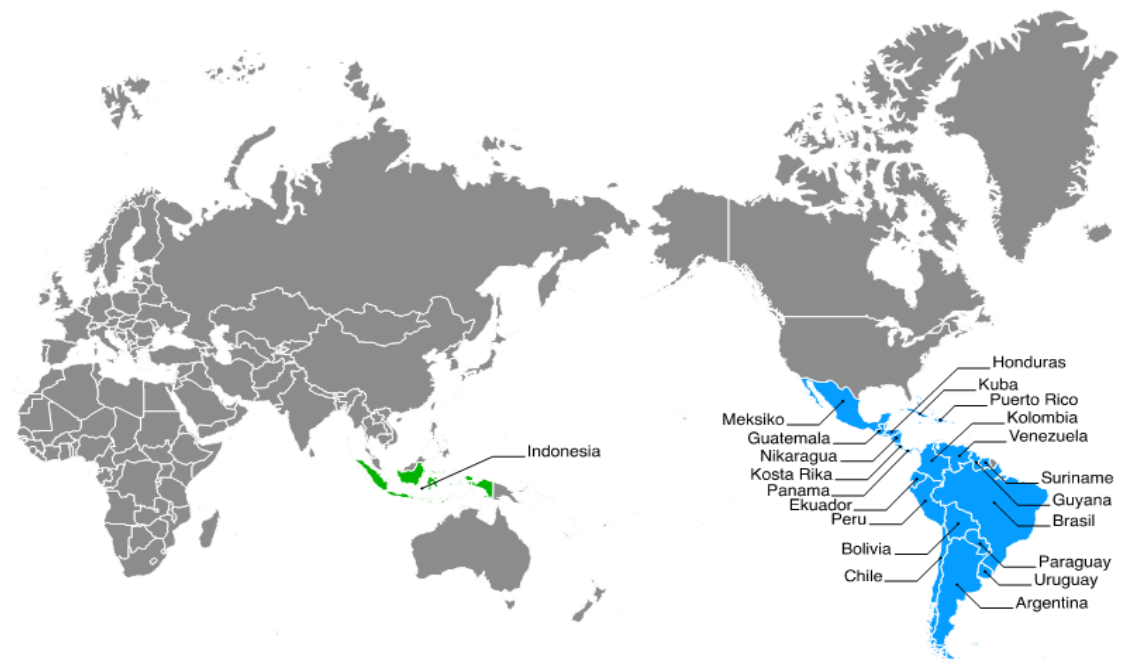

Sumber: Pusat P2K2 Amerika dan Eropa

Amerika Latin adalah kawasan dengan potensi sumber daya alam yang sangat kaya, antara lain, sebagai produsen utama hasil pertanian dan peternakan seperti kacang kedelai yang mencakup hampir 50\% produksi dunia, daging sapi yang mencakup hamper sepertiga produksi dunia, dan sepertiga persediaan air tawar dunia dan lahan potensial untuk pertanian. Kawasan ini juga penghasil utama mineral dan energi biofuel dunia. Amerika Latin merupakan salah satu kawasan dengan pertumbuhan ekonomi yang cukup tinggi selama beberapa tahun terakhir. Kekuatan ekonomi kawasan Amerika dapat terlihat dari peringkat World GDP (nominal) beberapa negara tahun 2014 dalam US Dollar (USD), antara lain: (1) Amerika Serikat adalah negara dengan GDP terbesar di dunia USD 17,947 triliun (IMF, 2015), (10) Kanada: GDP USD 1,552 miliar, (9) Brasil: GDP USD 1,773 miliar, (15) Meksiko: GDP USD 1,144 miliar, (21) Argentina: GDP USD 586 juta, (42) Chile: GDP USD 240 juta, (43) Venezuela: GDP 240 juta. Secara khusus untuk kawasan Amerika Latin, menurut data IMF, pada tahun 2015, GDP Brazil menduduki peringkat teratas (sekitar USD 1,7 miliar), disusul oleh Meksiko (USD 1,1 miliar) dan Argentina (USD 630 juta). Tren ini akan berlangsung sampai dengan beberapa tahun ke depan.

Tabel 2. GDP Negara-negara Kawasan Amerika Latin Periode 2015-2020 (dalam USD milyar)

\begin{tabular}{|c|r|r|r|r|r|r|}
\hline Amerika Utara \& Tengah & \multicolumn{1}{|c|}{$\mathbf{2 0 1 5}$} & \multicolumn{1}{c|}{$\mathbf{2 0 1 6}$} & \multicolumn{1}{c|}{$\mathbf{2 0 1 7}$} & \multicolumn{1}{c|}{$\mathbf{2 0 1 8}$} & \multicolumn{1}{c|}{$\mathbf{2 0 1 9}$} & \multicolumn{1}{c|}{$\mathbf{2 0 2 0}$} \\
\hline Meksiko & $1,143.796$ & $1,063.606$ & $1,124.316$ & $1,182.511$ & $1,250.764$ & $1,324.518$ \\
\hline Belize & 1.753 & 1.770 & 1.855 & 1.939 & 2.014 & 2.090 \\
\hline Guatemala & 63.794 & 68.389 & 71.984 & 76.817 & 82.022 & 87.493 \\
\hline Honduras & 20.450 & 20.930 & 21.406 & 22.065 & 22.794 & 23.547 \\
\hline El-Savador & 25.850 & 26.610 & 27.659 & 28.924 & 30.222 & 31.532 \\
\hline Nikarangua & 12.693 & 13.413 & 14.294 & 15.241 & 16.215 & 17.250 \\
\hline Kosta Rica & 52.898 & 57.689 & 61.534 & 65.872 & 70.357 & 75.227 \\
\hline Panama & 52.132 & 55.227 & 59.307 & 64.183 & 69.591 & 75.313 \\
\hline Amerika Selatan & $\mathbf{2 0 1 5}$ & $\mathbf{2 0 1 6}$ & $\mathbf{2 0 1 7}$ & $\mathbf{2 0 1 8}$ & $\mathbf{2 0 1 9}$ & $\mathbf{2 0 2 0}$ \\
\hline Venezuela & 260.089 & 333.715 & 314.103 & 210.164 & 198.041 & 192.750 \\
\hline Colombia & 292.091 & 274.135 & 300.988 & 325.195 & 352.059 & 380.615 \\
\hline
\end{tabular}


Jurnal Asia Pacific Studies

Volume 2 Number 2 / July - December 2018

\begin{tabular}{|c|c|c|c|c|c|c|}
\hline Amerika Utara \& Tengah & 2015 & 2016 & 2017 & 2018 & 2019 & 2020 \\
\hline Ekuador & 100.872 & 99.118 & 98.107 & 97.167 & 97.428 & 97.156 \\
\hline Peru & 192.113 & 180.291 & 192.619 & 204.857 & 217.226 & 230.374 \\
\hline Bolivia & 33.238 & 35.699 & 39.795 & 43.373 & 47.209 & 51.193 \\
\hline Chile & 240.233 & 234.903 & 242.641 & 253.973 & 266.550 & 280.483 \\
\hline Argentina & 630.448 & 541.748 & 594.975 & 651.335 & 709.466 & 773.445 \\
\hline Guyana & 3.164 & 3.456 & 3.691 & 3.860 & 4.056 & 4.247 \\
\hline Suriname & 5.150 & 4.137 & 4.442 & 4.802 & 5.061 & 5.257 \\
\hline Brazil & $1,772.589$ & $1,769.601$ & $1,953.861$ & $2,028.923$ & $2,118.323$ & $2,213.760$ \\
\hline Paraguay & 27.714 & 27.323 & 28.581 & 30.248 & 32.053 & 33.995 \\
\hline Uruguay & 53.107 & 54.374 & 58.145 & 61.535 & 65.275 & 69.002 \\
\hline Karibia & 2015 & 2016 & 2017 & 2018 & 2019 & 2020 \\
\hline Kuba & NA & NA & NA & NA & NA & NA \\
\hline Jamaika & 14.218 & 13.779 & 14.562 & 15.329 & 16.130 & 16.993 \\
\hline Haiti & 8.713 & 8.259 & 7.837 & 7.962 & 8.243 & 8.656 \\
\hline St.Vincent \&Grenadine & 0.738 & 0.766 & 0.797 & 0.830 & 0.865 & 0.904 \\
\hline Bahamas & 8.854 & 9.047 & 9.345 & 9.729 & 10.095 & 10.540 \\
\hline Rep Dominica & 0.517 & 0.524 & 0.548 & 0.573 & 0.599 & 0.626 \\
\hline St. KITTS\&Nevis & 0.915 & 0.955 & 1.006 & 1.062 & 1.117 & 1.173 \\
\hline Antigua\&Barbuda & 1.259 & 1.303 & 1.358 & 1.429 & 1.505 & 1.585 \\
\hline St Lucia & 1.431 & 1.439 & 1.513 & 1.587 & 1.661 & 1.738 \\
\hline Barbados & 4.385 & 4.473 & 4.640 & 4.853 & 5.083 & 5.327 \\
\hline Grenada & 0.984 & 1.028 & 1.090 & 1.146 & 1.202 & 1.263 \\
\hline Trinidad\&Tobago & 24.631 & 22.809 & 23.645 & 25.448 & 27.093 & 28.648 \\
\hline
\end{tabular}

Sumber: World Economic Outlook, IMF, 2016

Lebih lanjut, jika dilihat dari PDB per kapita (Purchasing Power Parity), maka dapat terlihat bahwa PDB per kapita di kawasan Amerika Latin mengalami peningkatan yang cukup pesat. Kawasan Amerika Latin termasuk salah satu dari tiga kawasan di dunia - Eropa Tengah dan Timur serta RRT dengan pertumbuhan kelas menengah (middle income class) yang cukup signifikan. Dalam kurun 2001-2011, populasi kelas menengah di kawasan Amerika Latin tumbuh 11\%, dari sekitar 16\% total populasi di kawasan pada tahun 2001 menjadi $27 \%$ di tahun 2011 (Gao 2015).

Di kawasan Amerika, Indonesia telah memiliki pasar tradisional yaitu dengan Amerika Serikat. Dalam hubungan dagang Indonesia dengan negara-negara kawasan Amerika, AS adalah mitra dagang utama yakni mencakup $87 \%$ dari total perdagangan Indonesia dengan kawasan Amerika Utara. AS merupakan mitra dagang terbesar ke-4 dengan total perdagangan USD 27 miliar. Sementara investasi AS sebesar USD 893,2 juta (2015) pada sektor pertambangan, jasa, makanan, dan alat transportasi dengan target investasi AS di Indonesia: USD 67 miliar (tahun 2015-2020). Pada bidang pariwisata, kunjungan wisatawan AS ke Indonesia tercatat sebanyak 251.221 orang (2015).

Kawasan Amerika Latin merupakan kawasan yang berkembang dinamis dengan karakteristik yang kuat, yaitu: 1) kemampuan mengatasi krisis ekonomi global dengan kondisi ekonomi yang relatif solid; 2) jumlah populasi yang besar; 3) masyarakat kelas menengah yang meningkat pesat; dan 4) meningkatnya urbanisasi dan industrialisasi yang semakin 
berkembang. Peluang yang dapat dimanfaatkan dari kawasan Amerika Latin, yaitu: (1) konektivitas dan infrastruktur di kawasan yang semakin membaik, seperti infrastruktur Bioceanic dan Trans-Andean Railways yang terintegrasi; (b) sebesar 99\% pasar di Amerika Latin belum dikelola dengan baik (impor Amerika Latin dari Indonesia hanya 0,32\% atau sekitar USD 1 triliun di tahun 2015); (c) terdapat banyak forum dan organisasi ekonomi di kawasan yang dapat dimanfaatkan. Amerika Latin memiliki konsumen potensial dengan kawasan integrasi ekonomi yang menyediakan banyak forum atau media, seperti Caricom, Mercosur, Pacific Alliance.

Negara-negara di kawasan Amerika Latin walaupun secara umum memiliki bahasa dan kemiripan sejarah namun dalam berbisnis dengan setiap negara memiliki seni dan cara yang sama sekali berbeda. Terlebih bahwa karakter dan jenis produk perdagangannya dapat dikatakan sangat beragam dan tidak sama (Becker 2011).

Peluang tersebutlah yang dapat dimanfaatkan dalam menjalin hubungan dagang dengan negara-negara Amerika Latin. Tantangan yang perlu dihadapi dalam mengembangkan hubungan ekonomi dengan kawasan Amerika Latin, antara lain: (a) jarak dan waktu shipping yang lebih dari 24 jam atau sekitar 5 hari melalui jalur laut (hal ini tentu saja menjadi pertimbangan bagi pengusaha ); (b) risiko bencana alam (di tahun 2016, kawasan ini telah mengalami berbagai bencana seperti Matthew Hurricane, gempa bumi di Ekuador dan gunung meletus di Chile); (c) instabilitas ekonomi-politik, seperti yang dialami di Venezuela sejak 2013 yang berdampak pada inflasi mencapai $370 \%$ pada tahun 2015, atau Brasil yang mengalami instabilitas politik ketika terjadi impeachment Presiden Dilma Rouseff pada Mei 2016.

Perundingan perdagangan potensial di masa mendatang adalah Indonesia-Chile CEPA, Indonesia-Peru PTA, WGTI Indonesia-Ekuador, dan WGTI Indonesia-Brazil. Indonesia dapat memanfaatkan forum sebagai anggota di APEC dan FEALAC, sebagai observer di Pacific Alliance, dan sebagai Non-Associate di Mercosur. Ada beberapa faktor yang tentunya perlu diperhatikan dalam menentukan pasar prospektif agar pencapaian target penetrasi dan ekspansi pasar dapat berjalan secara efektif dan efisien. Salah satu faktornya adalah populasi, pertumbuhan ekonomi, dan kategorisasi produk impor yang didatangkan oleh negara mitra dari Indonesia. Beberapa negara di kawasan Amerika Latin yang tergolong sebagai pasar prospektif menurut lembaga Global Edge adalah Brasil, Meksiko, Peru, Chile, Uruguay, El Savador, Argentina, dan Kosta Rika. Negara potensial Brazil, Meksiko, dan Peru.

Tabel 3. Market Potential Index Negara-negara Kawasan Amerika LatinTahun 2014-2016

\begin{tabular}{|c|c|c|c|}
\hline \multirow{2}{*}{ NEGARA } & \multicolumn{3}{|c|}{ PERINGKAT } \\
\cline { 2 - 4 } & $\mathbf{2 0 1 6}$ & $\mathbf{2 0 1 5}$ & $\mathbf{2 0 1 4}$ \\
\hline Brasil & 20 & 20 & 20 \\
\hline Meksiko & 36 & 38 & 25 \\
\hline Peru & 40 & 41 & 51 \\
\hline Chile & 44 & 40 & 32 \\
\hline Uruguay & 49 & 49 & 42 \\
\hline El Savador & 52 & 52 & 52 \\
\hline Argentina & 53 & 56 & 59 \\
\hline Costa Rica & \multicolumn{4}{|c|}{58} & 58 & 48 \\
\hline Sumber: Global Edge 2016
\end{tabular}


Bagi Indonesia, pasar prospektif di Kawasan Amerika Latin cukup banyak seperti Meksiko, Peru, Kolombia, Chile, Argentina, namun dalam rangka menetapkan fokus pasar tersebut, berdasarkan indeks MPI dan faktor-faktor perkembangan hubungan bilateral, dua negara yang ditetapkan sebagai sasaran pasar prospektif adalah: Meksiko dan Chile.

\subsection{Meksiko dan Chile sebagai Negara Pasar Prospektif di Kawasan Amerika Latin}

\section{Meksiko}

Meksiko merupakan negara Amerika Latin yang terletak di kawasan Amerika Tengah bersebelahan langsung dengan Amerika Serikat. Sehingga dari sisi jarak antara IndonesiaMeksiko hampir sama dengan Indonesia-Amerika Serikat. Saat ini Indonesia-Meksiko sedang dalam proses pencapaian kemitraan strategis 2020 melalui Plan of Action RI-Mexico 20162020. Hal tesebut guna penguatan diplomasi ekonomi Indonesia dalam bidang ketahanan pangan (impor sapi, ternak dan gandum) .

Nilai total perdagangan RI-Meksiko dalam lima tahun terakhir cukup stabil di atas USD 1 miliar. Dalam periode waktu yang sama, neraca perdagangan RI-Meksiko juga selalu mencatatkan surplus untuk RI. Nilai ekspor tertinggi RI ke Meksiko tercatat pada tahun 2014 sebesar USD 850,8 juta, sementara itu nilai impor tertinggi RI dari Meksiko tercatat pada tahun 2012 sebesar USD 568,4 juta. Pada tahun 2014 dan 2015, nilai surplus perdagangan RI menembus kisaran USD 600 juta sehingga menempatkan Meksiko sebagai negara penyumbang surplus perdagangan terbesar ketiga di kawasan Amerika setelah AS dan Brasil.

Tabel 4. Neraca Perdagangan Indonesia-Meksiko Periode 2011-2015

\begin{tabular}{|c|c|c|c|c|c|c|c|}
\hline Uraian & 013 & 014 & 015 & $\begin{array}{l}\text { rend } \\
(\%) \\
2011- \\
2015\end{array}$ & 015 & Jan-Agu & $\begin{array}{r}\text { Per } \\
\text { ub. } \\
2016 / 2015)\end{array}$ \\
\hline $\begin{array}{r}\text { TOTAL } \\
\text { PERDAGANGAN }\end{array}$ & $\begin{array}{r}1 . \\
203.068,0\end{array}$ & $\begin{array}{r}1 . \\
038.336,3\end{array}$ & $\begin{array}{r}1 . \\
021.560,8\end{array}$ & 2,51 & $83.535,9^{6}$ & $54.337,1^{6}$ & 4,27 \\
\hline MIGAS & $\begin{array}{r}5 \\
1.993,6\end{array}$ & $\begin{array}{r}3 \\
7.848,5\end{array}$ & $\begin{array}{r}2 \\
0.958,1\end{array}$ & 18,69 & $0.958,1^{2}$ & $1.293,0^{1}$ & 46,12 \\
\hline NON MIGAS & $\begin{array}{r}1 . \\
151.074,4\end{array}$ & $\begin{array}{r}1 . \\
000.487,8\end{array}$ & $\begin{array}{r}1 . \\
000.602,7\end{array}$ & 1,92 & $62.577,8^{6}$ & $43.044,{ }^{6}$ & 2,95 \\
\hline EKSPOR & $\begin{array}{r}6 \\
87.275,5\end{array}$ & $\begin{array}{r}8 \\
50.874,4\end{array}$ & $\begin{array}{r}8 \\
24.002,2\end{array}$ &, 45 & $40.501,3^{5}$ & $33.653,1^{5}$ & 1,27 \\
\hline MIGAS & $\begin{array}{r}5 \\
1.993,6\end{array}$ & $\begin{array}{r}3 \\
7.730,0\end{array}$ & $\begin{array}{r}2 \\
0.830,5\end{array}$ & 18,81 & $0.830,5^{2}$ & $1.293,0^{1}$ & 45,79 \\
\hline NON MIGAS & $\begin{array}{r}6 \\
35.281,9\end{array}$ & $\begin{array}{r}8 \\
13.144,4\end{array}$ & $\begin{array}{r}8 \\
03.171,7\end{array}$ &, 03 & $19.670,8^{5}$ & $22.360,1^{5}$ & $\begin{array}{r}0,5 \\
2\end{array}$ \\
\hline IMPOR & $\begin{array}{r}5 \\
15.792,5\end{array}$ & $\begin{array}{r}1 \\
87.462,0\end{array}$ & $\begin{array}{r}1 \\
97.558,5\end{array}$ & 22,76 & $43.034,6^{1}$ & $20.684,0^{1}$ & 15,63 \\
\hline MIGAS & $\begin{array}{r}0, \\
0\end{array}$ & $\begin{array}{r}1 \\
18,5\end{array}$ & $\begin{array}{r}1 \\
27,5\end{array}$ &, 00 & $27,5^{1}$ & ${ }_{, 0}$ & - \\
\hline NON MIGAS & $\begin{array}{r}5 \\
15.792,5\end{array}$ & $\begin{array}{r}1 \\
87.343,4\end{array}$ & $\begin{array}{r}1 \\
97.431,0\end{array}$ & 22,77 & $42.907,1^{1}$ & $20.684,0^{1}$ & 15,55 \\
\hline NERACA & 1 & 6 & 6 & & 3 & 4 & 3,9 \\
\hline
\end{tabular}


Jurnal Asia Pacific Studies

Volume 2 Number 2 / July - December 2018

\begin{tabular}{|c|c|c|c|c|c|c|c|}
\hline PERDAGANGAN & $71.483,0$ & $63.412,4$ & $26.443,7$ & 8,72 & $97.466,7$ & $12.969,0$ & $\mathbf{0}$ \\
\hline MIGAS & $\begin{array}{r}5 \\
1.993,6\end{array}$ & $\begin{array}{r}3 \\
7.611,5\end{array}$ & $\begin{array}{r}2 \\
0.703,0\end{array}$ & 18,93 & $0.703,0^{2}$ & $1.293,0^{1}$ & - \\
\hline NON MIGAS & $\begin{array}{r}1 \\
19.489,5\end{array}$ & $\begin{array}{r}6 \\
25.800,9\end{array}$ & $\begin{array}{r}6 \\
05.740,7\end{array}$ & 2,63 & $76.763,7^{3}$ & $01.676,0^{4}$ & $\begin{array}{r}6,6 \\
1\end{array}$ \\
\hline
\end{tabular}

Sumber : Kementerian Perdagangan 2015

Melihat data impor Meksiko dari dunia periode 2011-2015 di atas, terlihat komoditas yang banyak diimpor oleh Meksiko. Melihat kemampuan produk ekspor Indonesia (komoditas utama dan potensial) maka Indonesia dapat memanfaatkan peluang ekspor untuk komoditas: produk kertas (Indonesia peringkat teratas di antara kompetitor ASEAN); produk farmasi (bersaing dengan Singapura), produk kimia (teratas di antara kompetitor ASEAN), otomotif (bersaing dengan Thailand), besi dan baja (bersaing dengan Vietnam), dan karet dan produk karet (bersaing dengan Thailand. Indonesia juga berpotensi untuk mendorong ekspor produk plastik (bersaing dengan Thailand, Singapura dan Malaysia); furnitur (bersaing dengan Malaysia dan Vietnam), dan tembaga (bersaing dengan Malaysia).

Dari sisi investasi, nilai investasi Meksiko pada tahun 2014, 2015, dan 2016 tercatat 0 (data Badan Koordinasi Penanaman Modal/BKPM menggunakan satuan juta dolar, yang artinya terdapat investasi dari Meksiko ke Indonesia akan tetapi nilainya sangat kecil). Investasi dari Meksiko tercatat pada sektor hotel dan restoran, perdagangan, reparasi, industri makanan, industri logam dasar, barang logam, mesin dan elektronik. Dalam bidang investasi, Meksiko memfokuskan investasinya di sektor perkebunan alpukat dan pembibitan sapi, sementara investasi Indonesia di Meksiko pada sektor joint production of radioisotope.

Negara-negara MIKTA juga merupakan bagian dari kelompok G-20 yang memiliki sebagian besar sumberdaya, teknologi, produksi, pasar, dan perputaran keuangan dunia. Dalam G-20, posisi Indonesia berada di peringkat ke-16, didahului oleh empat anggota MIKTA lainnya dan diikuti oleh Turki. Mengingat besarnya potensi dari negara-negara anggota MIKTA, bagi Indonesia forum informal ini dilihat sebagai media untuk meningkatkan kerja sama riil antara negara-negara anggota baik di bidang ekonomi, perdagangan maupun sosial dan budaya.

Penguatan hubungan ekonomi dengan Meksiko dapat dilihat dengan merujuk pada upaya RRT dan Vietnam di negara ini. Momentum penguatan kerja sama ekonomi RRT dan Meksiko dimulai pada tahun 2014 yang didukung dengan priorita pemerintah Meksiko untuk membuka diri terhadap mitra ekonomi di luar NAFTA, khususnya dengan Asia, melalui strategi "diversification of its economic ties". RRT merupakan sumber impor terbesar ke-2 bagi Meksiko. Di tahun 2014, impor Meksiko dari RRT mencapai 16,6\% sedangkan ekspor Meksiko ke RRT baru mencapai $1,5 \%$.

Investasi RRT di Meksiko belum terlalu besar yakni sekitar 0,1\% namun diharapkan akan terus meningkat dalam jangka pendek. Hubungan keduanya juga semakin erat melalui berbagai proyek infrastruktur RRT di Meksiko dan pembentukan beberapa lembaga untuk memfasilitasi kerja sama ekonomi RRT-Meksiko, khususnya sejak kemenangan presiden terpilih AS Donald Trump, kedua negara sepakat untuk lebih mempererat hubungan ekonomi. Sedangkan Vietnam, walaupun tidak memiliki perjanjian perdagangan dengan Meksiko, namun negara ini merupakan mitra perdagangan terbesar kedua bagi Meksiko di Amerika Latin. Pada tahun 2015, nilai perdagangan bilateral kedua negara mencapai USD 1,7 miliar atau naik 57\%. Skema TPP diharapkan dapat lebih meningkatkan nilai perdagangan ini, khususnya untuk produk-produk elektronik, besi dan baja, dan makanan ternak. 
Uraian di atas telah menggambarkan potensi ekonomi Meksiko sebagai pasar prospektif dan mitra ekonomi bilateral Indonesia yang masih menawarkan banyak peluang untuk dioptimalkan, tidak saja dari aspek hubungan antarpemerintah tetapi juga dari aspek hubungan sektoral dan people-to-people contact. Forum MIKTA dan G20 menjadi media yang dapat dimanfaatkan untuk lebih mendekatkan hubungan bilateral dan mendorong kerja sama ekonomi yang saling menguntungkan di antara kedua negara.

\section{Chile}

Chile merupakan negara yang peranannya penting di kawasan yang ditunjukkan salah satunya dengan keaktifannya di beberapa forum regional dan multilateral diantaranya AsiaPacific Economic Cooperation (APEC) dan Trans Pacific Partnership (TPP). Chile memiliki stabilitas ekonomi paling baik di kawasan Amerika Selatan sehingga menjadi negara tujuan pekerja migran dari negara-negara tetangga sekitar di kawasan. Sementara Indonesia adalah anggota negara G-20 dan merupakan negara dengan ekonomi terbesar di Asia Tenggara dan memiliki peran leading pada ASEAN.

Sementara itu, dari sisi neraca ekonomi, volume perdagangan Indonesia-Chile periode 2009 hingga 2014 cenderung bersifat fluktuatif, namun masih cukup prospektif. Pada tahun 2014 tercatat volume perdagangan kedua negara sebesar USD 419,4 juta atau meningkat dari tahun 2013 sebesar USD 412,0 juta. Indonesia mengalami defisit perdagangan dengan Chile tahun 2014 sebesar USD 63,6 juta. Produk impor utama Indonesia yaitu tembaga, biji besi, selulosa, tepung dan minyak ikan, buah segar dan wine. Sementara produk ekspor Indonesia seperti: gas alam, batu bara, karet alam, minyak kelapa sawit, produk tekstil, footwear, peralatan elektronik dan suku cadang kendaraan bermotor.

Tabel 5. Neraca Perdagangan Indonesia-Chile Periode 2011-2015

\begin{tabular}{|c|c|c|c|c|c|c|c|c|c|}
\hline \multirow[b]{2}{*}{ Uraian } & \multirow[b]{2}{*}{2011} & \multirow[b]{2}{*}{2012} & \multirow[b]{2}{*}{2013} & \multirow[b]{2}{*}{2014} & \multirow[b]{2}{*}{2015} & \multirow{2}{*}{$\begin{array}{c}\text { Trend } \\
(\%) \\
2011- \\
2015\end{array}$} & \multicolumn{2}{|c|}{ Jan-Agu } & \multirow{2}{*}{$\begin{array}{c}\text { Perub. } \\
(\%) \\
2016 \\
/ 2015\end{array}$} \\
\hline & & & & & & & 2015 & 2016 & \\
\hline $\begin{array}{c}\text { TOTAL } \\
\text { PERDAGANGAN }\end{array}$ & $586.228,4$ & $381.987,5$ & 412.015,0 & 419.405,5 & 321.197,4 & $-10,50$ & $213.189,3$ & $158.364,3$ & $-25,72$ \\
\hline MIGAS & 0,0 & 0,0 & 0,0 & 0,0 & 0,0 & 0,00 & 0,0 & 0,0 & 0,00 \\
\hline NON MIGAS & $586.228,4$ & $381.987,5$ & $412.015,0$ & $419.405,5$ & $321.197,4$ & $-10,50$ & $213.189,3$ & $158.364,3$ & $-25,72$ \\
\hline EKSPOR & $213.966,9$ & $175.346,5$ & $170.766,8$ & $177.899,1$ & $147.349,5$ & $-7,05$ & $96.467,0$ & 93.847,1 & $-2,72$ \\
\hline MIGAS & 0,0 & 0,0 & 0,0 & 0,0 & 0,0 & 0,00 & 0,0 & 0,0 & 0,00 \\
\hline NON MIGAS & $213.966,9$ & $175.346,5$ & $170.766,8$ & $177.899,1$ & $147.349,5$ & $-7,05$ & $96.467,0$ & $93.847,1$ & $-2,72$ \\
\hline IMPOR & $372.261,5$ & $206.640,9$ & 241.248,2 & $241.506,4$ & $173.847,9$ & $-12,78$ & $116.722,3$ & $64.517,1$ & $-44,73$ \\
\hline MIGAS & 0,0 & 0,0 & 0,0 & 0,0 & 0,0 & 0,00 & 0,0 & 0,0 & 0,00 \\
\hline NON MIGAS & $372.261,5$ & $206.640,9$ & $241.248,2$ & $241.506,4$ & $173.847,9$ & $-12,78$ & $116.722,3$ & $64.517,1$ & $-44,73$ \\
\hline $\begin{array}{c}\text { NERACA } \\
\text { PERDAGANGAN }\end{array}$ & $-158.294,6$ & $-31.294,4$ & $-70.481,3$ & $-63.607,3$ & $-26.498,4$ & $-24,91$ & $-20.255,2$ & $29.330,0$ & 244,80 \\
\hline MIGAS & 0,0 & 0,0 & 0,0 & 0,0 & 0,0 & 0,00 & 0,0 & 0,0 & 0,00 \\
\hline NON MIGAS & $-158.294,6$ & $-31.294,4$ & $-70.481,3$ & $-63.607,3$ & $-26.498,4$ & $-24,91$ & $-20.255,2$ & $29.330,0$ & 244,80 \\
\hline
\end{tabular}

Sumber: Kementerian Perdagangan 2016 
Dalam upaya peningkatan hubungan perdagangan, Indonesia - Chile telah menandatangani pernyataan bersama dan pengesahan Term of Reference (TOR) IndonesiaChile Comprehensive Economic Partnership Agreement (IC - CEPA) pada 2013. Sebagai tindak lanjut, pada tanggal 26-27 Mei 2014 di Santiago telah dilaksanakan perundingan pertama perjanjian perdagangan Trade in Goods (TiGs). Saat ini, Chile telah mempunyai 28 perjanjian perdagangan bebas (FTA) dan perjanjian bebas tarif terbatas dengan 65 negara di dunia termasuk Uni Eropa, Amerika Serikat, Kanada, Jepang, dan Thailand. Ketersediaan infrastruktur pelabuhan laut dan jalan darat yang menjadikan Chile pintu masuk ideal ke negara-negara tetangga. Pembangunan tol lintas bi-oceanico dari kota pelabuhan Iquique, Chile, ke pelabuhan Santos di Brasil, meningkatkan arus barang dari Asia Pasifik ke Amerika Latin.

Dampak lebih jauh dari kesepakatan tersebut adalah pemanfaatan posisi Chile sebagai jalan pembuka untuk mengakses pasar kawasan Amerika Selatan dan negara lain yang juga memiliki perjanjian perdagangan bebas dengannya. Sebagai bagian dari upaya peningkatan ekspor diharapkan identifikasi perluasan pasar berbagai negara yang berpotensi untuk menjadi tujuan ekspor (untapped market) diharapkan dapat mendukung pencapaian target ekspor Indonesia. Berdasarkan data yang diperoleh dari Kepala Pusat Pengkajian Kebijakan Perdagangan Luar Negeri, Kementerian Perdagangan pada diskusi terbatas tanggal 12 Maret 2015, disampaikan bahwa Chile merupakan salah satu negara yang berpotensi sebagai untapped market bagi produk Indonesia.

Melihat data impor Chile dari dunia periode 2011-2015 di atas, terlihat komoditas yang banyak diimpor. Melihat kemampuan produk ekspor Indonesia (komoditas utama dan potensial), Indonesia dapat memanfaatkan peluang ekspor untuk komoditas: produk kertas (Indonesia pada peringkat teratas di antara kompetitor ASEAN); alas kaki (peringkat 3 setelah Vietnam); tekstil dan produk tekstil (peringkat 7 dan 9 setelah Vietnam); produk karet (peringkat 25 setelah Malaysia dan Thailand); otomotif (peringkat 26 setelah Thailand). Indonesia juga berpotensi mendorong ekspor produk mesin (Indonesia berada di peringkat 31 setelah Vietnam, Malaysia, dan Filipina; biji besi dan baja (pada posisi 37 setelah Thailand dan Vietnam); dan minyak atsiri (pada posisi 48 setelah Filipina, Singapura, Thailand, dan Malaysia); dan produk kimia (pada peringkat 26 setelah Malaysia dan Singapura).

Upaya penguatan ekonomi yang dapat dilihat di Chile, antara lain, adalah upaya Vietnam melalui pembentukan perjanjian perdagangan atau FTA dengan Chile yang berlaku sejak 2014. Sejak FTA berlaku, perdagangan barang oleh kedua negara tumbuh sekitar $26,8 \%$ dalam 5 tahun terakhir. Peningkatan ini disumban dari produk-produk ekspor yang dapat menikmati pengurangan tarif dalam kerangka FTA, seperti ekspor produk kayu Vietnam ke Chile (tumbuh 15-18\% dalam sepuluh tahun terakhir) dan produk minuman anggur asal Chile yang menikmati penurunan tarif $36 \%$ ke pasar Vietnam yang memiliki kelas menengah yang sedang tumbuh pesat. Interaksi ekonomi yang lebih kuat diharapkan dapat berkembang dalam kerangka TTP. Uraian di atas telah menggambarkan potensi Chile sebagai pasar prospektif bagi Indonesia. Keterbukaan ekonomi Chile yang terefleksi dari berbagai kesepakatan perdagangan bebas yang dijalin oleh negara ini dengan berbagai mitra di dunia dapat dimanfaatkan dengan menjadikan Chile sebagai pintu gerbang bagi pemajuan kerja sama ekonomi Indonesia dengan kawasan Amerika Latin.

\section{E. Kesimpulan}

Dari assesment dan emerging economies di Kawasan Amerika yang dapat menjadi salah satu fokus pemerintah dalam upaya diplomasi ekonomi dengan pertimbangan populasi, pertumbuhan ekonomi, dan kategorisasi produk impor yang didatangkan dari Indonesia ke 
negara mitra prospektif tersebut, dapat diidentifikasi bahwa pasar non-tradisional yang prospektif, yaitu Chile dan Meksiko untuk kawasan Amerika Latin yang merupakan anggota Pacific Alliance.

Meksiko merupakan salah satu mitra dagang prospektif Indonesia. Indonesia selalu memperoleh surplus perdagangan dengan Meksiko, bahkan menempati negara urutan ketiga penyumbang surplus perdagangan dengan Indonesia di Kawasan Amerika setelah AS dan Brasil. Sebagai salah satu negara anggota MIKTA dalam G20 sebagaimana Indonesia, kerjasama Indonesia-Meksiko juga dapat memanfaatkan forum informal ini untuk meningkatkan kerja sama riil di bidang ekonomi termasuk perdagangan serta kerja sama di bidang sosial dan budaya.

Chile merupakan salah satu negara dengan peranan dan kiprah penting baik dalam forum Asia-Pacific Economic Cooperation (APEC) maupun negosiasi Trans-Pacific Partnership. Chile juga memiliki stabilitas ekonomi yang cukup baik di kawasan Amerika Latin. Meskipun volume perdagangan kedua negara cukup fluktuatif, namun masih cukup prospektif. Hubungan Chile dan Indonesia juga potensial. Kedua negara perlu mengoptimalkan peningkatan hubungan perdagangan melalui Indonesia-Chile Comprehensive Economic Partnership Agreement. Chile juga diharapkan dapat menjadi jalan pembuka untuk mengakses pasar kawasan Amerika Latin dan negara-negara yang memiliki perjanjian perdagangan bebas dengan Chile. Sementara itu, investasi dari Chile masih sangat perlu didorong. 


\section{DAFTAR PUSTAKA}

\section{Buku}

Baranay, Pavol. 2009. Modern Economic Diplomacy. Riga: Publications of Diplomatic Economic Club.

Bayne, Nicholas, and Woolcock, Stephen. 2007. The New Economic Diplomacy: DecisionMaking and Negotiation in International Economic Relations. London: Ashgate Publishing.

Becker, Thomas H. 2011. Doing Business in the New Latin America: Keys to Profit in America's Next Door. The 2nd Edition. Connecticut: Praeger.

Goodwin, Paul B. 2011. Global Studies, Latin America and The Carribean. The 14th Edition". London: The McGrawHill.

Okano-Heijmans, Maaike. 2013. Introduction Economic Diplomacy: Japan and the Balance of National Interest. Leiden: Martinus Nijhoff Publishers.

\section{Dokumen}

Badan Perencanaan Pembangunan Nasional. 2015. "Rencana Pembangunan Jangka Menengah Nasional 2015-2019. Buku II, Agenda Pembangunan Bidang”. Jakarta: Kementerian Perencanaan Pembangunan Nasional.

Marsudi, Retno L.P.2016. Pernyataan Pers Menteri Luar Negeri. Jakarta. 7 Januari.

\section{Surat Kabar}

Hutabarat, Leonard F. 2016. "Diplomasi Ekonomi Berbasis Maritim". Tribun Manado. Manado. 16 Februari.

2016. "Persaingan Kebijakan TPP”. Pikiran Rakyat. Bandung. 26 Mei.

\section{Website}

Cavusgil, S. Tamer, Knight, Gary, \& Riesenberger, John. 2013. "International Business, the new realities, $3^{\text {rd }}$ edition", 12 Januari. Diakses pada: http://userwww.sfsu.edu/ nyang/IBUS\%20330/PPT\%20Yang\%202015/NYPPT15_files/Ch10.ppt.

Crawford, Jo-Ann, \& Fiorentino, Roberto V. 2009. "Changing landscape of Regional trade Agreements", WTO, 10 Februari. Diakses pada: https://www.wto.org/english/ res_e/booksp_e/discussion_papers8e.pdf, hal. 4 \& 5 .

Cummings, Rafe. 2014. "Regional Economic Integration", Pearson Education. Diakses pada: http://slideplayer.com/slide/5286149/.

Gao, George. 2015. "Latin America's middle class grows, but in some regions more than others", Pew Research Center, 20 Juli. Diakses pada: http://www.pewresearch .org/fact-tank/2015/07/20/latin-americas-middle-class-grows-but-in-some-regionsmore-than-others/. 
Icef Monitor. 2014. "The Growing Role of Emerging Markets In Shaping Global Demand", 6 Maret. Diakses pada: http://monitor.icef.com/2014/03/the-role-of-emerging-marketsin-shaping-global-demand/.

IMF. 2016. "World Economic Outlook (WEO) Update, Subdued Demand, Diminished Prospects, January 2016", Januari. Diakses pada: http://www.imf.org/ external/pubs/ft/weo/2016/update/01/. . 2016. "Frequently Asked Questions World Economic Outlook (WEO)", 4 Oktober. Diakses pada: https://www.imf.org/external/pubs/ft/weo/faq.htm.

Lagarde, Christine. 2016. 'The role of emerging markets in a New Global Partnership for Growth by IMF Managing Director Christine Lagarde', IMF, 4 Februari. Diakses pada: http://www.imf.org/external/np/speeches/2016/020416.htm.

Moon, Chung-in. 2007. "Economic Regionalism”, Encyclopedia Britannica, 18 Juni. Diakses pada: https://www.britannica.com/topic/economic-regionalism.

Republika. 2016. "Mengikis Hambatan Dagang Minyak Sawit", 15 Februari. Diakses pada: http://www.republika.co.id/berita/koran/teraju/16/02/15/o2ku4626-mengikishambatan-dagang-minyak-sawit.

Santosa, Eddi. 2015. “Tembus US\$ 1,04 juta, RI Genjot Bisnis dengan Meksiko", Detik, 01 Juni. Diakses pada: http://finance.detik.com/berita-ekonomi-bisnis/d-2930940 /tembus-us-104-miliar-ri-genjot-bisnis-dengan-meksiko.

Walley, John. 1998. "Why do countries seek regional trade agreement?", The National Bureau of Economic Research, Januari. Diakses pada: http://www.nber.org/ chapters/c7820.pdf.

World Trade Organization. 2016. "Regional Trade Agreements: Fact and Figures", 1 Februari. Diakses pada: https://www.Wto.Org/English/Tratop_E/Region_E/ Regfac_E.Htm. 